\title{
MOCVD KINETICS OF STRONTIUM BISMUTH TANTALATE THIN FILM GROWTH
}

\author{
M. Šilinskas, M. Lisker, B. Kalkofen, S. Matichyn, and E. Burte \\ Institute of Micro- and Sensor Systems, Otto von Guericke University, Universitätsplatz 2, 39106 Magdeburg, Germany
}

Received 26 May 2004

Dedicated to the 100th anniversary of Professor K. Baršauskas

\begin{abstract}
The thin films of $\mathrm{BiO}_{x}, \mathrm{Sr}_{x} \mathrm{Ta}_{y} \mathrm{O}_{z}$, and strontium bismuth tantalate (SBT) were deposited by metalorganic chemical vapour deposition (MOCVD) on $150 \mathrm{~mm}$ silicon (100) wafers. Some of the wafers were pre-deposited with Pt electrodes. The substrate temperature and the deposition pressure were varied from 300 to $600{ }^{\circ} \mathrm{C}$ and from 0.35 to $7 \mathrm{mbar}$, respectively. $\mathrm{Bi}(/ / /)_{3}$ (triallyl bismuth) and $\mathrm{Sr}\left[\mathrm{Ta}(\mathrm{OEt})_{5}\left(\mathrm{OC}_{2} \mathrm{H}_{4} \mathrm{OMe}\right)\right]_{2}$ (strontium bis[tantalum(pentaethoxy)(2-methoxyethoxide)] were used as a $\mathrm{Bi}$ precursor and as a $\mathrm{Sr}-\mathrm{Ta}$ precursor, respectively. A liquid delivery system was used to supply and to evaporate the precursor into the reactor. X-ray photoelectron spectroscopy (XPS) and ellipsometry were carried out to characterize the film properties. The growth rate of the MOCVD of $\mathrm{BiO}_{x}$ and $\mathrm{Sr}_{x} \mathrm{Ta}_{y} \mathrm{O}_{z}$ was compared to the growth rate of SBT to obtain information about mutual interaction between precursors. The deposition rate of bismuth oxide thin films was low $(\sim 10 \mathrm{~nm} / \mathrm{h}$ at 0.35 mbar $)$ and did virtually not depend on the temperature. On the contrary, the growth rate of strontium tantalate films depended strongly on the temperature. The deposition rate of the SBT films was similar to the bismuth oxide film deposition, which slightly increased with increasing substrate temperature. However, the deposition rate of SBT was always lower than the deposition rate of the single precursors. The growth rate significantly depends on pressure. The decrease of the deposition pressure in the reactor chamber reduces the deposition rate of $\mathrm{BiO}_{x}, \mathrm{Sr}_{x} \mathrm{Ta}_{y} \mathrm{O}_{z}$, and $\mathrm{SBT}$, but on the other hand, it improves the uniformity of the film thickness. The XPS measurements showed a deficit of bismuth in the SBT films even though the concentration of the $\mathrm{Bi}$ precursor was several times higher. The XPS depth-profiling by $\mathrm{Ar}^{+}$ion sputtering indicated different bond characteristics of $\mathrm{Ti}, \mathrm{Sr}$, and Bi before and after ion beam bombardment.
\end{abstract}

Keywords: metalorganic chemical vapour deposition, SBT, XPS

PACS: 81.15.Gh, 77.84.-s, 79.60.-i

\section{Introduction}

Ferroelectric thin films have attracted great interest for nonvolatile ferroelectric random access memory (FeRAM) applications [1-3]. These materials have some advantages over silicon-based memories such as faster write speed and lower operating voltage [4]. $\mathrm{Pb}\left(\mathrm{Zr}_{x} \mathrm{Ti}_{1-x}\right) \mathrm{O}_{3}$ (PZT) has been the most intensively studied material for this application. However, PZT thin films with Pt electrodes exhibit serious degradation of ferroelectric properties with cumulative polarization which is known as polarization fatigue $[3,5]$. Recently, alternative $\mathrm{SrBi}_{2} \mathrm{Ta}_{2} \mathrm{O}_{9}$ (SBT) materials have been widely used because of their excellent fatigue endurance $[3,6]$.

Various deposition techniques such as metalorganic decomposition (MOD), pulsed laser deposition (PLD), sol-gel method, metalorganic chemical vapour deposition (MOCVD) were used for SBT thin film deposi- tion [7,8]. The MOCVD process has become widely accepted in the semiconductor industry because of the superior step coverage, better control of composition and thickness, and better uniformity over large wafer size compared to other deposition techniques [3,9].

In this study, we present SBT deposition using MOCVD. The growth rate of the MOCVD of $\mathrm{BiO}_{x}$ and $\mathrm{Sr}_{x} \mathrm{Ta}_{y} \mathrm{O}_{z}$ was compared to the growth rate of SBT to obtain information about mutual interaction between precursors. We focused our research on the film growth kinetics, the thickness uniformity, and the elemental composition.

\section{Experimental}

The $\mathrm{BiO}_{x}, \mathrm{Sr}_{x} \mathrm{Ta}_{y} \mathrm{O}_{z}$, and SBT thin films were deposited by MOCVD (Fig. 1) at reduced pressure. A liquid delivery system (LDS) was used to supply and to evaporate the precursor into the reactor. The flows 


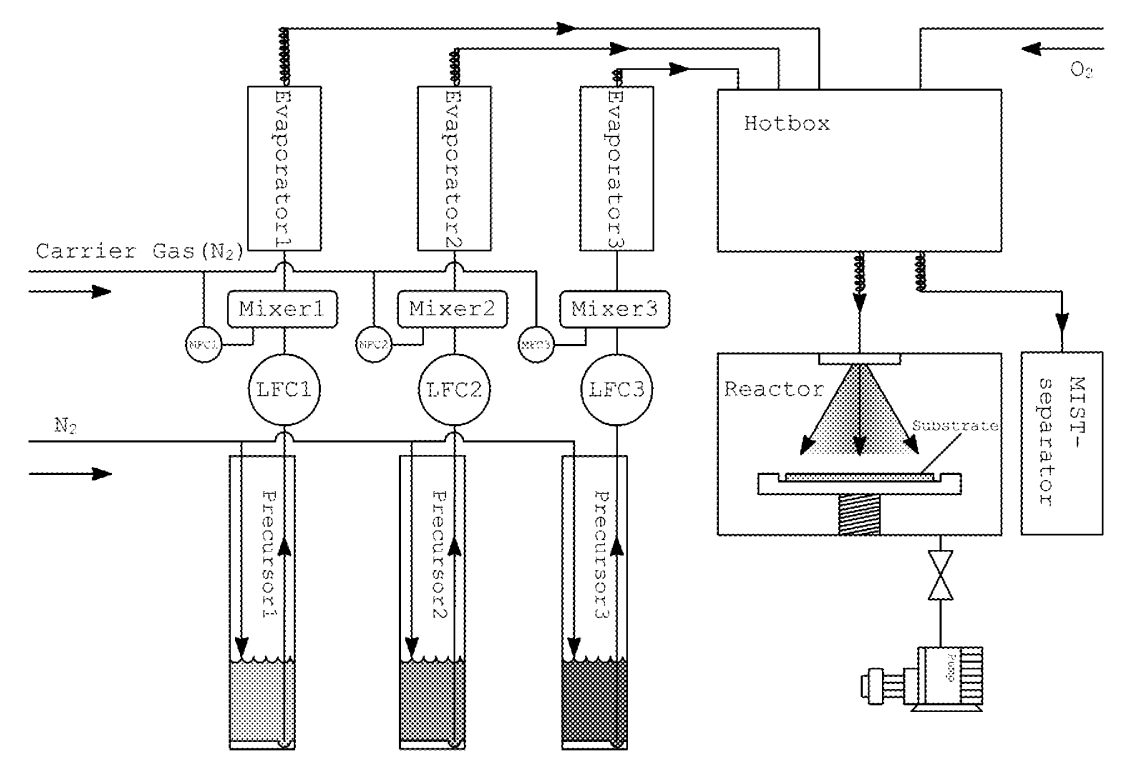

Fig. 1. Schematic diagram of the MOCVD system.

of the precursors were adjusted using liquid flow controllers (LFC). The temperature of the evaporator was varied from 140 to $180^{\circ} \mathrm{C}$. The precursor vapours were carried by nitrogen gas set to a flow rate of $50 \mathrm{sccm}$ to the hot-box that was heated to $160^{\circ} \mathrm{C}$ where they were mixed with the oxygen which was supplied with a flow rate of $50 \mathrm{sccm}$. The flows of the gases were controlled by mass flow controllers (MFC). The connecting lines between the evaporator, the hot-box, and the reactor were heated to $160^{\circ} \mathrm{C}$ in order to prevent the condensation of the precursor. The deposition zone was resistively heated to the deposition temperatures ranged from 350 to $650{ }^{\circ} \mathrm{C}$. The MOCVD reactor was equipped with a vacuum pump system and a motordriven pendulum valve to adjust the pressure during the deposition process in a range between 0.35 and 7 mbar. During the film deposition, the reactor wall temperature was maintained between 60 and $80^{\circ} \mathrm{C}$.

The $\mathrm{BiO}_{x}, \mathrm{Sr}_{x} \mathrm{Ta}_{y} \mathrm{O}_{z}$, and SBT thin films were deposited on $150 \mathrm{~mm}$ silicon (100) wafers by means of MOCVD. Some of the wafers were pre-deposited with Pt electrodes. $\mathrm{Bi}(/ / /)_{3}$ (triallyl bismuth) and $\mathrm{Sr}\left[\mathrm{Ta}(\mathrm{OEt})_{5}\left(\mathrm{OC}_{2} \mathrm{H}_{4} \mathrm{OMe}\right)\right]_{2}$ (strontium bis[tantalum (pentaethoxy)(2-methoxyethoxide)] were used as a $\mathrm{Bi}$ precursor and as a $\mathrm{Sr}-\mathrm{Ta}$ precursor, respectively. The precursors were dissolved in toluene $0.05 \mathrm{M}$ for $\mathrm{BiO}_{x}$ and $\operatorname{Sr}_{x} \operatorname{Ta}_{y} \mathrm{O}_{z}$ film deposition. A mixture of the two precursor solutions was made for SBT deposition. In this case, the concentration of the Bi precursor was two times higher $(0.1 \mathrm{M})$. The deposition conditions are summarized in Table 1.
Table 1. Growth conditions of $\mathrm{BiO}_{x}, \mathrm{Sr}_{x} \mathrm{Ta}_{y} \mathrm{O}_{z}$, and SBT thin films.

\begin{tabular}{lc}
\hline Bi precursor & $\mathrm{Bi}(/ / /)_{3} /$ toluene $(0.05 \mathrm{~mol} / \mathrm{l})$ \\
Sr-Ta precursor & $\mathrm{Sr}\left[\mathrm{Ta}(\mathrm{OEt})_{5}\left(\mathrm{OC}_{2} \mathrm{H}_{4} \mathrm{OMe}\right)\right]_{2} /$ toluene \\
SBT precursor & $(0.05 \mathrm{~mol} / \mathrm{l})$ \\
& $\mathrm{Bi}(/ / /)_{3} / \mathrm{toluene}(0.1 \mathrm{~mol} / \mathrm{l})$ and \\
& $\mathrm{Sr}\left[\mathrm{Ta}(\mathrm{OEt})_{5}\left(\mathrm{OC}_{2} \mathrm{H}_{4} \mathrm{OMe}\right)\right]_{2} /$ toluene \\
Deposition temperature & $(0.05 \mathrm{~mol} / \mathrm{l})$ \\
Deposition pressure & $350-650^{\circ} \mathrm{C}$ \\
Evaporator temperature & $0.35-7 \mathrm{mbar}$ \\
Carrier gas $\left(\mathrm{N}_{2}\right)$ flow rate & $140-180^{\circ} \mathrm{C}$ \\
$\mathrm{O}_{2}$ flow rate & $50 \mathrm{sccm}$ \\
Precursor flow rate & $50 \mathrm{sccm}$ \\
Deposition time & $0.05-1 \mathrm{~g} / \mathrm{h}$ \\
\hline
\end{tabular}

The film thickness was measured by a spectroscopic ellipsometer (Sentech SE850). Data were taken within the $248-869 \mathrm{~nm}$ wavelength range.

The elemental composition was analysed by X-ray photoelectron spectroscopy (XPS) using ESCA 5600 (Mg $K_{\alpha}$ line). The XPS depth-profiling was made by $4.5 \mathrm{keV} \mathrm{Ar}^{+}$ion bombardment.

\section{Results and discussion}

In order to estimate the SBT deposition rate and elemental composition, the MOCVD process was investigated for $\mathrm{Bi}$ and $\mathrm{Sr}-\mathrm{Ta}$ precursors separately. Figure 2 shows the dependences of growth rates for $\mathrm{Bi}$, $\mathrm{Sr}-\mathrm{Ta}$, and $\mathrm{Bi}-\mathrm{Sr}-\mathrm{Ta}$ precursors at different reactor temperatures and at a pressure of 0.35 mbar. The deposition rate of the bismuth oxide thin films was low $(\sim 10 \mathrm{~nm} / \mathrm{h})$ and did virtually not depend on the tem- 


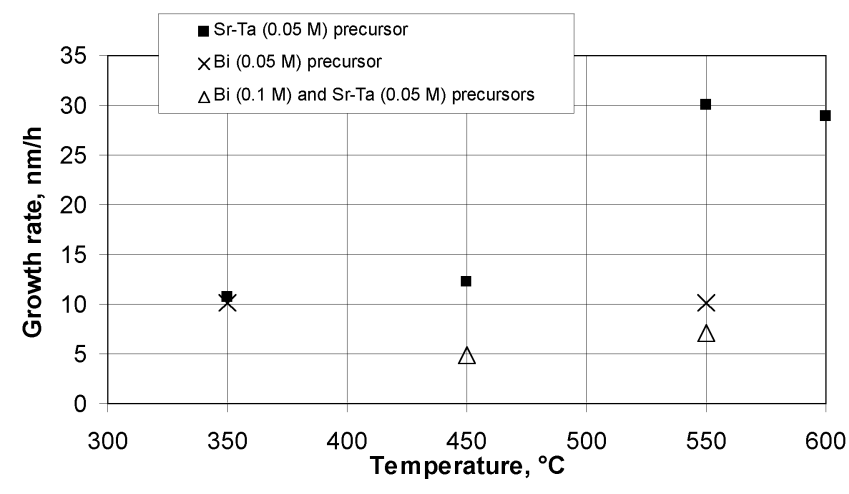

Fig. 2. Growth rate of $\mathrm{BiO}_{x}, \mathrm{Sr}_{x} \mathrm{Ta}_{y} \mathrm{O}_{z}$, and $\mathrm{SBT}$ thin films as a function of the substrate temperature at 0.35 mbar pressure.

perature. On the contrary, the growth rate of strontium tantalate films depended strongly on the temperature. Three characteristic ranges were determined for $\mathrm{Sr}-\mathrm{Ta}$ precursors. The first one was observed at low temperatures $\left(350-450{ }^{\circ} \mathrm{C}\right)$. In this range, the surface was not enough activated and the deposition rate was low and almost constant $(\sim 12 \mathrm{~nm} / \mathrm{h})$. In the second range $\left(450-550^{\circ} \mathrm{C}\right)$, the process was reaction rate limited. The activation energy was calculated in this region and was equal to $45 \mathrm{~kJ} / \mathrm{mol}$. Above $550{ }^{\circ} \mathrm{C}$, the deposition rate saturated at $30 \mathrm{~nm} / \mathrm{h}$ and a mass transport rate limited regime was observed. The deposition rate dependence $(5-8 \mathrm{~nm} / \mathrm{h})$ of the SBT films was similar to the Bi film deposition that slightly increased with increasing substrate temperature. But the rate was lower than the deposition rate of the single precursors.

The growth rate significantly depended on the deposition pressure (see Fig. 3). Having increased the pressure from 0.35 mbar to $3.5 \mathrm{mbar}$, the deposition rate of SBT rose from $7 \mathrm{~nm} / \mathrm{h}$ to $45 \mathrm{~nm} / \mathrm{h}$ at a temperature of $550^{\circ} \mathrm{C}$. The changes were not so pronounced at reduced substrate temperatures. The growth rate increased from 5 to $15 \mathrm{~nm} / \mathrm{h}$ at $450{ }^{\circ} \mathrm{C}$. Figure 3 also shows that the growth rate of SBT was always less than the growth rate of $\mathrm{Sr}_{x} \operatorname{Ta}_{y} \mathrm{O}_{z}$. However, another pressure-related effect was observed. The decrease of the deposition pressure in the reactor chamber reduced the deposition rate of $\mathrm{BiO}_{x}, \mathrm{Sr}_{x} \mathrm{Ta}_{y} \mathrm{O}_{z}$, and SBT. But on the other hand, the pressure reduction improved the uniformity of the film thickness (see Fig. 4), which is very important for microelectronical applications. Figure 4 presents a distribution of the film thickness over the entire $150 \mathrm{~mm}$ wafer at pressures of 0.35 and 3.5 mbar. The increase of the substrate temperature improved the film uniformity only at reduced pressure. A standard deviation of the films thickness decreased from $7 \%$ at $350{ }^{\circ} \mathrm{C}$ to $3-4 \%$ at $550{ }^{\circ} \mathrm{C}$. The film thick-

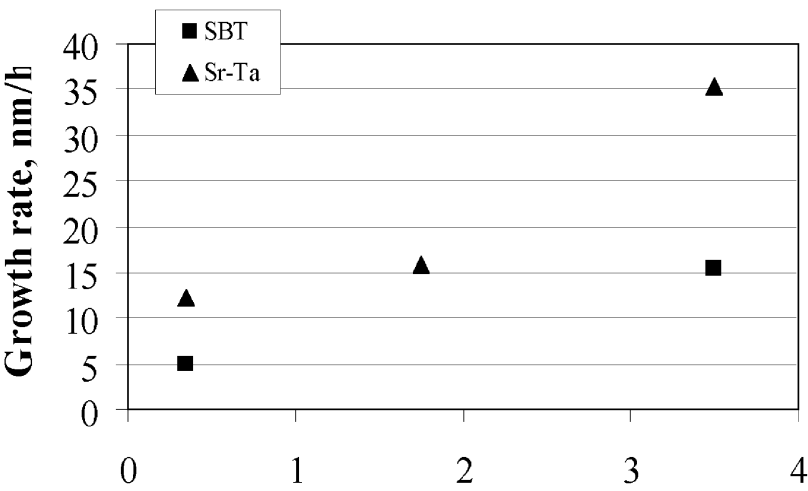

Pressure, mbar

(a)

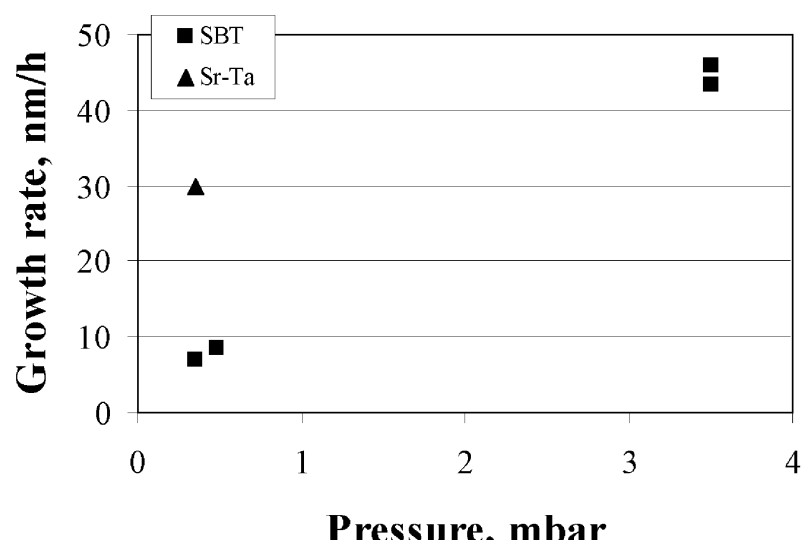

(b)

Fig. 3. Growth rate of $\mathrm{Sr}_{x} \mathrm{Ta}_{y} \mathrm{O}_{z}$ and SBT thin films as a function of the pressure at (a) $450{ }^{\circ} \mathrm{C}$ and (b) $550{ }^{\circ} \mathrm{C}$ substrate temperature.

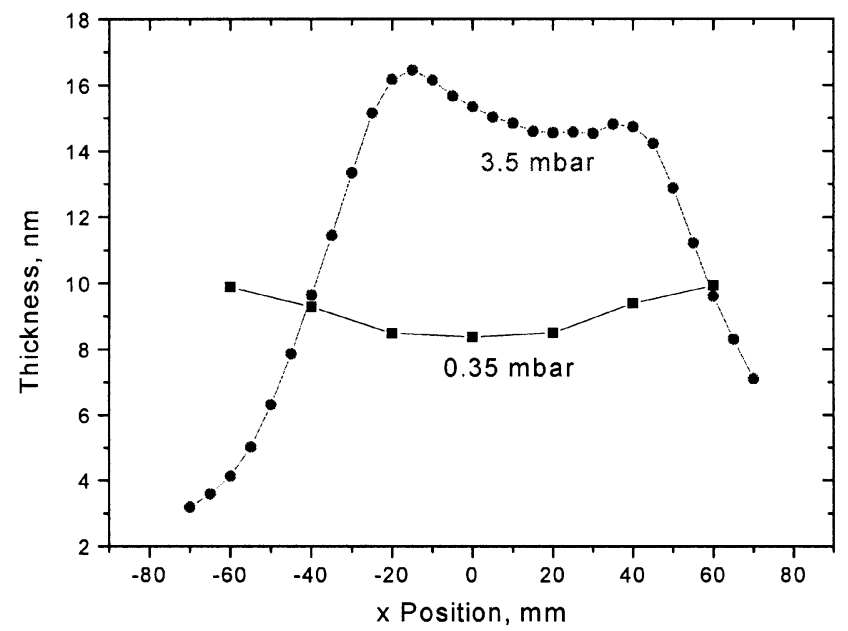

Fig. 4. Film thicknes as a function of the position on the wafer $(150 \mathrm{~mm})$ at $550{ }^{\circ} \mathrm{C}$.

ness was more inhomogeneous at higher pressure and the standard deviation of the film thickness exceeded $35 \%$. In this case, there was no correlation between 


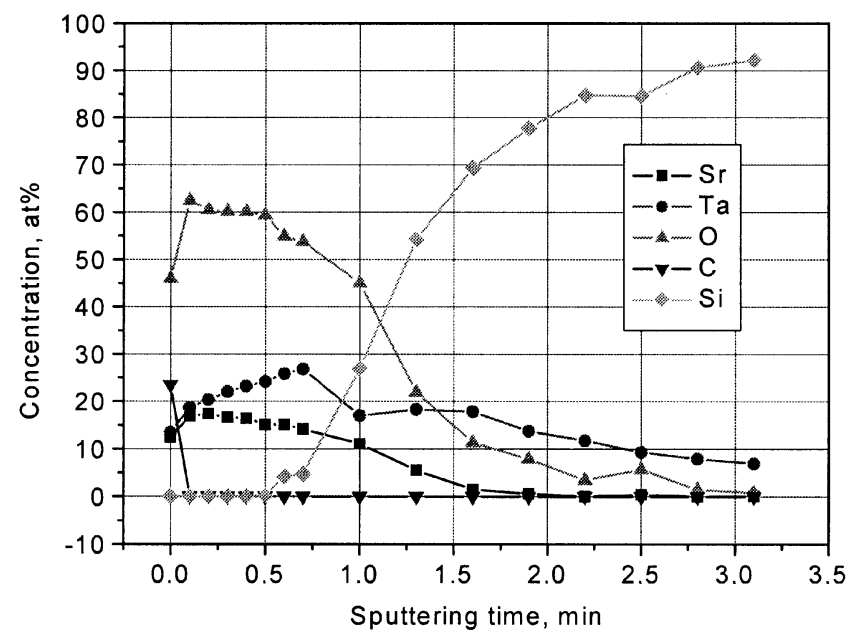

Fig. 5. Atomic composition of $\mathrm{Sr}_{x} \mathrm{Ta}_{y} \mathrm{O}_{z}$ thin films (defined by XPS) as a function of $\mathrm{Ar}^{+}$ion sputtering time. The SBT thin films were deposited on silicon wafer at $550{ }^{\circ} \mathrm{C}, 0.35 \mathrm{mbar}$, and $50 \mathrm{sccm} \mathrm{O}_{2}$.

the uniformity of the film thickness and the substrate temperature.

The growth rate depended on evaporation temperature. The decrease of the temperature of the evaporator from 140 to $180^{\circ} \mathrm{C}$ resulted in a reduced growth rate of the $\mathrm{Sr}_{x} \mathrm{Ta}_{y} \mathrm{O}_{z}$ films of about $10 \%$. A variation of the growth rate of $\mathrm{BiO}_{x}$, and SBT was not so significant and did not exceed 5\%.

The XPS measurements of $\mathrm{Sr}_{x} \mathrm{Ta}_{y} \mathrm{O}_{z}$ indicated that the surface layer of these films contained 24 at. $\%$ carbon, 46 at.\% oxygen, 14 at.\% strontium, and 15 at.\% tantalum (see Fig. 5). No more carbon was observed after $\mathrm{Ar}^{+}$ion bombardment. This means that the substrate temperature and oxygen content were sufficient for growing carbon-free films. The other components showed a different behaviour with increased sputter time. At first, the amount of $\mathrm{Sr}, \mathrm{O}$, and $\mathrm{Ta}$ atoms increased, related to the disappearing of carbon. After that the content of $\mathrm{Sr}$ and $\mathrm{O}$ decreased. An enhancement tendency of the concentration of Ta remained in the whole $\mathrm{Sr}_{x} \mathrm{Ta}_{y} \mathrm{O}_{z}$ film. One explanation could be that the sputtering yield of $\mathrm{Ta}$ is three times lower than for other elements. The Ta content in the silicon wafer also supports this assumption, while the Ta concentration in the silicon wafer is about 9 at.\% and diffusion at this temperature is insignificant.

The elemental composition of the SBT thin films is presented in Fig. 6. Because of the low thickness of the films, Pt (about 2 at.\%) was observed through the surface layer. The surface concentration of the other elements were as follows: $\mathrm{Bi} \sim 3$ at.\%, C 32 at.\%,

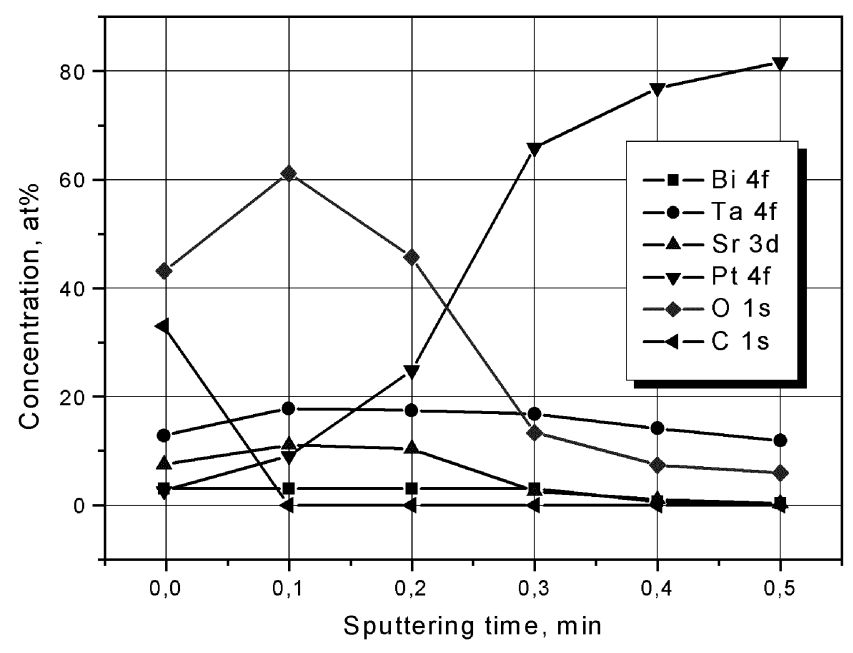

Fig. 6. Atomic composition of SBT thin films (defined by XPS) as a function of $\mathrm{Ar}^{+}$ion sputtering time. The SBT thin films were deposited on $\mathrm{Pt}(100 \mathrm{~nm})$ coated silicon wafer at $550{ }^{\circ} \mathrm{C}, 0.35 \mathrm{mbar}$, and $50 \mathrm{sccm} \mathrm{O}_{2}$.

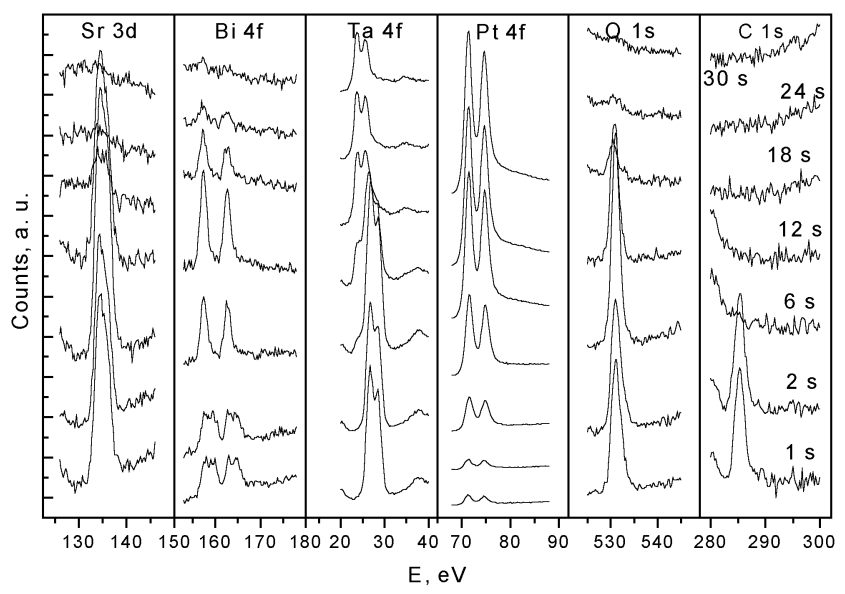

Fig. 7. XPS spectra of $\mathrm{Sr} 3 d$, Bi $4 f$, Ta $4 f$, Pt $4 f$, O $1 s$, and $\mathrm{C} 1 s$ at different $\mathrm{Ar}^{+}$ion sputtering time. The SBT thin films were deposited on $\mathrm{Pt}(100 \mathrm{~nm})$ coated silicon wafer at $550{ }^{\circ} \mathrm{C}, 0.35 \mathrm{mbar}$, and $50 \mathrm{sccm} \mathrm{O}_{2}$.

Ta 13 at. $\%$, Sr 9 at.\%, and $\mathrm{O} 41$ at.\%. As in the $\mathrm{Sr}_{x} \mathrm{Ta}_{y} \mathrm{O}_{z}$ case, carbon was observed only in the surface layer, the concentration of the other analysed elements increased after the first sputtering step. The XPS measurements of SBT showed a deficit of bismuth even though the concentration of the Bi precursor was two times higher $(0.1 \mathrm{M})$ than the concentration of the $\mathrm{Sr}-$ Ta precursor $(0.05 \mathrm{M})$ (see Fig. 6). The content of $\mathrm{Bi}$ in the SBT thin films was very sensitive to the oxygen concentration in the deposition gas mixture. When no oxygen was used, the concentration of $\mathrm{Bi}$ was about 1 at. $\%$.

The XPS spectra of $\mathrm{Sr} 3 d$, Bi $4 f$, Ta $4 f$, Pt $4 f$, $\mathrm{O} 1 s$, and $\mathrm{C} 1 s$ at different $\mathrm{Ar}^{+}$ion sputtering time are 
presented in Fig. 7. The peak positions of Ta $4 f_{5 / 2}$ $(27.9 \mathrm{eV}), \mathrm{Ta} 4 f_{7 / 2}(26.6 \mathrm{eV}), \mathrm{Sr} 3 d_{3 / 2}(135.1 \mathrm{eV})$, $\mathrm{Sr} 3 d_{5 / 2}(133.5 \mathrm{eV}), \mathrm{Bi} 4 f_{5 / 2}(159.1 \mathrm{eV})$, and $\mathrm{Bi} 4 f_{7 / 2}$ $(164.4 \mathrm{eV})$ indicated that these elements were in the oxide state. Different bond characteristics of Ta, Sr, and $\mathrm{Bi}$ were observed close to the surface than below after $\mathrm{Ar}^{+}$ion bombardment (see Fig. 7). The peaks of Sr, $\mathrm{Ta}$, and $\mathrm{Bi}$ shifted to lower energy. This means that the chemical state of $\mathrm{Sr}$, Ta, and $\mathrm{Bi}$ changed from oxide state to metallic, resulting from a preferential sputtering of oxygen atoms [10].

\section{Conclusion}

The growth kinetics and elemental composition of $\mathrm{BiO}_{x}, \mathrm{Sr}_{x} \mathrm{Ta}_{y} \mathrm{O}_{z}$, and $\mathrm{SBT}$ thin films were investigated using $\mathrm{Bi}(/ / /)_{3}$ (triallyl bismuth), $\mathrm{Sr}\left[\mathrm{Ta}(\mathrm{OEt})_{5}\left(\mathrm{OC}_{2^{-}}\right.\right.$ $\mathrm{H}_{4} \mathrm{OMe}$ ) $]_{2}$ (strontium bis[tantalum(pentaethoxy)- (2methoxyethoxide)] precursors. The deposition of SBT thin films was more similar to $\mathrm{BiO}_{x}$ than to $\mathrm{Sr}_{x} \mathrm{Ta}_{y} \mathrm{O}_{z}$. The increase of the deposition temperature to $600{ }^{\circ} \mathrm{C}$ and pressure to 3.5 mbar lead to a higher deposition rate. But the uniformity of the film thickness over the $150 \mathrm{~mm}$ wafer was not sufficient. The standard deviation was about $35 \%$ at a pressure of 3.5 mbar. The higher temperature of $600^{\circ} \mathrm{C}$ and lower pressure of 0.35 mbar were more suitable for microelectronic applications.

\section{Acknowledgements}

The work was financially supported by the Deutsche Forschungsgemeinschaft. The authors would like to thank Dr. N. Schindler for XPS measurements and Dr. J.Y. Hyon for preparing precursors.

\section{References}

[1] J. Baliga, Semicond. Intern. 23, 83 (2000).

[2] L. Mendicino, V. Vartanian, B. Goolsby, and P. Brown, Semicond. Intern. 25, 61 (2002).

[3] T. Li, Y. Zu, S.B. Desu, C.-H. Peng, and M. Nagata, Appl. Phys. Lett. 68, 616 (1996).

[4] S. Zafar, V. Kaustik, P. Laberge, P. Chu, R. Hance, P. White, D. Taylor, B. Melnick, and S. Gillespie, J. Appl. Phys. 82, 4469 (1997).

[5] K. Amanuma, T. Hase, and Y. Miyasaka, Appl. Phys. Lett. 66, 221 (1995).

[6] D. Wang, T. Yu, A. Hu, D. Wu, A. Li, Z. Liu, and N. Ming, Appl. Phys. Lett. 79, 2237 (2001).

[7] N. Nukaga, M. Mitsuya, and H. Funakubo, Jpn. J. Appl. Phys. 39, 5496 (2000).

[8] R. Dat, J. Lee, O. Auciello, and A. Kingon, Appl. Phys. Lett. 67, 572 (1995).

[9] N. Nukaga, M. Saito, K. Okuwada, and H. Fanakubo, Jpn. J. Appl. Phys. 41, 710 (2002).

[10] Y. Park, K. Min, K. Cho, S. Heo, C. Lim, M. Lee, T. Lee, H. Kim, and Y. Kim, J. Vac. Sci. Technol. A 19, 916 (2001).

\title{
STRONCIO BISMUTO TANTALATO DANGU AUGINIMO KINETIKA, NAUDOJANT METALOORGANINI CHEMINI GARU NUSODINIMO METODA
}

\author{
M. Šilinskas, M. Lisker, B. Kalkofen, S. Matichyn, E. Burte \\ Otto von Guericke universitetas, Magdeburgas, Vokietija
}

\begin{abstract}
Santrauka
$\mathrm{BiO}_{x}, \mathrm{Sr}_{x} \mathrm{Ta}_{y} \mathrm{O}_{z}$ ir stroncio bismuto tantalato (SBT) dangos buvo sudaromos and $150 \mathrm{~mm}$ silicio (100) padekklo, naudojant metaloorganini chemini garų nusodinimo metodą iš $\mathrm{Bi}(/ / /)_{3}$ (trialilbismuto) ir iš $\mathrm{Sr}\left[\mathrm{Ta}(\mathrm{OEt})_{5}\left(\mathrm{OC}_{2} \mathrm{H}_{4} \mathrm{OMe}\right)\right]_{2}$ (stroncio bis[tantalo (pentaetoksi)(2-metoksietoksido)]). Dangoms apibūdinti naudojome spektroskopinę elipsometriją ir Röntgen'o spinduliu fotoelektronu spektroskopiją (RFS). Norint teisingai parinkti SBT auginimo sąlygas, iš pradžiu tyrème bismuto oksido bei stroncio tantalato auginimo kinetiką. Paaiškejjo, kad bismuto oksidas auga
\end{abstract}

lètai $(\sim 10 \mathrm{~nm} / \mathrm{h}$, esant 0,35 mbar slègiui), o jo auginimo sparta beveik nepriklauso nuo temperatūros. Priešingai, stroncio titanato auginimo sparta labai priklauso nuo temperatūros. SBT auginimo sparta buvo mažesnè nei $\mathrm{BiO}_{x}, \mathrm{Sr}_{x} \mathrm{Ta}_{y} \mathrm{O}_{z}$, ir ji buvo būdingesne $\mathrm{BiO}_{x}$. Dangu auginimo sparta taip pat labai priklausè ir nuo slègio kameroje: didejant slègiui, didejo nusodinimo sparta, bet kartu didejo ir plèvelès storio netolygumai. Naudojant RFS, parodyta, kad dangose trūksta bismuto, net jei $\mathrm{Bi}(/ / /)_{3}$ koncentracija du kartus didesnè už $\mathrm{Sr}\left[\mathrm{Ta}(\mathrm{OEt})_{5}\left(\mathrm{OC}_{2} \mathrm{H}_{4} \mathrm{OMe}\right)\right]_{2}$ koncentraciją. 